\title{
REGIONAL ECONOMIC EFFECTS OF THE EUROPEAN CAPITAL OF CULTURE PROJECT: THE USE OF INPUT-OUTPUT ANALYSIS
}

\author{
Marta Nosková
}

\section{Introduction}

Topics such as economy of culture, the impact of culture on the economic development of regions, or multiplier effects of culture have begun to be quite popular in recent years not only in foreign literature, but also in the Czech Republic, where the evaluation research is rather rare (Slach \& Ježek, 2015). Good examples might be the works of Raabová (2010), who studied the cultural sectors in the Czech Republic and their effects on the economy, Llop \& ArauzoCarod (2011), who studied economic impact of a new museum, Herrero et al. (2006), who analysed the effects of the European Capital of Culture 2002 Salamanca, or Dunlop et al. (2004), who dealt with the economic effects of cultural industries in Scotland.

Culture can be defined according to Oxford Advanced Learner's Dictionary of Current English (2002) as a general term for art, music and literature. The first efforts to determine its value occurred in the 1990s in England when this subject was actively treated by local government. Arts and culture was until then seen only as a marginal part of the economy and mostly dependent on public subsidy. "Advocates of the creative industries idea believed that this was too narrow a view" (British Council, 2011, p. 15) and wanted culture to be understood for its true contribution. Under the new term cultural and creative industries they did not recognize "just the traditional art forms such as theatre, music and film, but service businesses such as advertising (which sell their creative skills mostly to other businesses), manufacturing processes that feed into cultural production, and the retail of creative goods" (British Council, 2011, p. 15). Thus from this broad classification, it is clear that the impact of cultural and creative sector is very significant. Also the European Commission acknowledges that it employs more than eight million people and produces about $4.5 \%$ of European GDP (European Commission, 2013). It is also clear that the economic impact of culture (respectively cultural and creative industries) generally is too broad topic, within which it is possible to deal with cultural impacts (theatre, movie, arts etc.) as well as the impacts of film industry, architecture, book industry and others. Thus it is advisable to narrow the topic.

In this paper, the attention will be paid to the European Capital of Culture (hereinafter referred to as "ECoC"), which is a title awarded annually to two cities in Europe, where varied cultural programme is then implemented during the year and often also some investment in the local cultural and recreational infrastructure is made. ECoC aims "to safeguard, develop and promote European cultural and linguistic diversity, to promote Europe's cultural heritage and to strengthen the competitiveness of the European cultural and creative sectors, in particular that of the audio-visual sector, with a view to supporting smart, sustainable and inclusive growth" (Decision No 445/2014/ $E U$, p. 2). In terms of ECoC, culture is seen as goods and services "consumed" on the spot (e.g. a concert) as well as production of cultural products aimed at mass reproduction (e. g. a book) and activities such as design or architecture (European Commission, 2006). This approach will be used in this paper.

ECoCs are very often analysed for its economic impacts on country, region or city. The most famous evaluation report is Palmer report (2004) that assesses the overall impacts of ECoCs 1995-2004, where a part is dedicated 
to economic impacts. Other very sophisticated reports were made for ECoC 2008 Liverpool including some that analysed economic impacts (Impacts 08, 2010). Also already mentioned Herrero et al. (2006) dealt with impacts of ECoC as well as Hudec and Džupka (2014), who studied culture-led regeneration of the city on the example of Košice (ECoC, 2013). In addition, there are regularly published several reports summarizing the impacts of the particular ECoC.

In 2015 the Pilsen Region in the Czech Republic became the centre of various cultural activities as a result of the "ECoC 2015" title obtained by the City of Pilsen. Recently, the title has been awarded to medium sized cities (e.g. Pécs, Maribor, Kosice and Pilsen) in comparison to the cultural centres that obtained the title earlier such as Athens, Paris or Florence. The title can help build the image of a cultural metropolis and also contribute to the development of chosen cities, not only thanks to the aforementioned investments, but also thanks to attracting tourists from all corners of the world (assuming that everything is supported by high-quality city marketing see Ježek (2010)). Attracting visitors and the resultant economic benefits are often one of the main interests of particular ECoC (Liu, 2014) and are also the main consequences, because according to Šebová et al. (2014, p. 655) there may be "link between the European Capital of Culture (ECoC) designation and the development of cultural tourism in Europe". Thus the ECoC title can serve as a great example to show that culture does not have to be only a non-profit activity, but it can also bring considerable funds to the region, especially in case of major cultural events, such as the ECoC.

Recently, economic effects of culture are often calculated using multipliers derived from input-output tables (e.g. Herrero et al., 2006, Llop \& Arauzo-Carod, 2011, or Impacts $08,2010)$. This paper aims to indicate the possible impacts of Pilsen ECoC 2015 project using the input-output modelling as well. The input-output analysis is usually made for the whole countries, because it is derived from the national symmetric input-output tables published by local statistical office. However, ECoC projects have mostly regional or even only municipal economic effects, because culture is mainly concentrated in large cities
(Slach et al., 2013). In the case of Pilsen ECoC 2015 project the mostly affected would be naturally the City of Pilsen. However, some events of Pilsen ECoC 2015 project took place outside the City of Pilsen and thus some funds were spent elsewhere in the region. Moreover it is not possible to derive symmetric input-output tables for the City of Pilsen (because of lack of municipal data).

Thus in order to calculate economic impact of Pilsen ECoC 2015 the regional input-output tables for the Pilsen Region were compiled and then were derived appropriate multipliers for industries that are related to culture (culture in this case is understood as a collective term of art, music and literature) or may be affected by a larger increase of tourists due to the interesting cultural programme (accommodation, meals, transportation, etc.) This paper aims only to indicate the effect of $\mathrm{ECoC}$ on the region as well as to show the economic importance of culture generally. It is not yet possible to assess the exact economic impact of Pilsen ECoC 2015 project because the resulting multipliers needs to be multiplied by data that are not yet processed and the calculation of this impact is a subject of the future research.

The first part of this paper deals with a selected method of calculating the multipliers, i.e. input-output analysis. First, it is introduced and then the procedure of multiplier derivation from the symmetric input-output tables published by the Czech Statistical Office is briefly explained. However, the crucial part of the paper is the computation of the regional input-output tables for the Pilsen Region. Compiling these tables for smaller territorial units (compared to countries) is not common and even the Czech Statistical Office does not compile them. Nevertheless, there are several methods to estimate them, even though it is not a commonly treated subject. In the Czech Republic, for example, Bednaříková (2012) estimated input-output tables for the Vysočina Region. In the last part of the paper, the multipliers are calculated and the results are presented.

\section{Input-Output Analysis}

In the thirties Wassily Leontief published his essay "Quantitative Input-Output relations in the economic system of the United States" (1936). The main idea of his work was that "economic activity of the whole country is 
visualized as if it were covered by one huge accounting system" (Leontief, 1936, p. 106). Each business enterprise from all branches of industry, agriculture, transportation as well as private persons and their budgets are treated as a separate accounting unit. The table includes all purchases and sales within a period of time (usually a year) in the country and it is balanced. It is in fact the table of inputs and outputs of the whole economy.

Although he was rightly first in inputoutput modelling, he was not the only one who addressed himself to these ideas. Quesnay Francoise, who compiled the so-called "Tableau Economique" in 1758, is often considered to be his predecessor. It describes economic production using a tabular array. This issue was also greatly contributed to by Leon Walras with his analysis of the overall balance from 1954. According to Bednaríková (2012), the inputoutput analysis is actually an effective application of the Walrasian general equilibrium analysis, namely due to the fact that it is composed of "a system of simultaneous equations describing the demand for the supply of sectorial outputs" (Bednaříková, 2012, p. 267).

The fifties of the 20th century were the period of the greatest expansion of the inputoutput modelling in the USA. Scientists in the USA developed this model not only for economies of entire countries, but also for regions or industries, and found that it can be utilized for the development policy and planning (Impacts 08, 2008). For instance, Isard (1953) dealt with regional and inter-regional commodity flows in order to build a regional input-output model and also Leontief elaborated this issue in his book entitled "Input-Output Economics" from 1951 (1986).

\section{Multipliers in General}

The input-output analysis is nowadays bound up with the terms of multiplier effects and multipliers. However, it is necessary to note that the original Leontief's concept does not operate with multipliers at all and their connection to input-output analysis occurred later. The idea of the multiplier effect and multipliers was first introduced by Kahn (1931) in his paper called "The Relation of Home Investment to Unemployment", but it was more fundamentally developed by Keynes in his famous work entitled "General Theory of Employment, Interest and Money" (1936).
The mostly used multipliers nowadays are multipliers type 1: (direct + indirect effects) I direct effects where the result of 2 means doubling the direct effects and the type 2: (direct + indirect + induced effects) / direct effects, which includes the increased economic activity caused by household expenditures occurred as a result of their increased income due to the higher economic activity of companies. (Bednaříková, 2008; The Scottish Government, 2011). Type 1 multiplier is used more frequently and can be derived from unmodified published symmetric input-output tables. The calculation of type 2 multipliers requires only simple modifications of published tables.

\section{Symmetric Input-Output Tables in the Czech Republic}

Symmetric input-output tables (hereinafter referred to as "SIOT") constitute the basis of Input-Output (hereinafter referred to as "I-O") analysis. They show flows between all sectors of the economy, i.e. inputs and outputs of each sector of the economy (in the Czech SIOT there are 82 sectors according to the CZ-CPA classification). Each sector is showed both in one row and one column, i.e. SIOT show both the demand side (columns) and the supply side (rows). For a better explanation see Tab. 1, which shows a simplified SIOT with three fundamental sectors.

To calculate output multipliers, the following tables are needed: a transactions table (SIOT), a table of technical coefficients, a table of comprehensive consumption coefficients.

The supply side (rows) shows that the overall resources are either consumed in the production process (intermediate consumption, $\left.z_{i j}\right)$ or they are used finally $\left(y_{i}\right)$. As for the demand side (columns), it is evident that the resources are produced by inputs of intermediate consumption $\left(z_{i j}\right)$ and added value $\left(v_{j}\right)$. The equality of total resources is expressed by two equations, which "create a balanced model from which all other relations within the structural analysis are derived" (Rojíček, 2007, p. 135).

Another table, which must be compiled, is a table of the input coefficients (also sometimes referred to as direct coefficients, direct consumption coefficients or direct requirement coefficients). The input coefficients matrix is calculated by normalizing data in SIOT according to the line of total resources, i.e., 


\section{Tab. 1: Transactions table}

\begin{tabular}{|c|c|c|c|c|c|}
\hline \multirow[b]{2}{*}{ Inputs|Outputs } & \multicolumn{3}{|c|}{ Intermediate consumption } & \multirow[b]{2}{*}{$\begin{array}{c}\text { Final use in } \\
\text { total }\end{array}$} & \multirow[b]{2}{*}{$\begin{array}{l}\text { Used resour- } \\
\text { ces in total }\end{array}$} \\
\hline & $\begin{array}{l}\text { Primary } \\
\text { sector }\end{array}$ & $\begin{array}{l}\text { Secondary } \\
\text { sector }\end{array}$ & $\begin{array}{l}\text { Tertiary } \\
\text { sector }\end{array}$ & & \\
\hline Primary sector & $z_{11}$ & $z_{12}$ & $\mathrm{z}_{13}$ & $\mathrm{y}_{1}$ & $x_{1}$ \\
\hline Secondary sector & $z_{21}$ & $\mathrm{z}_{22}$ & $\mathrm{z}_{23}$ & $\mathrm{y}_{2}$ & $x_{2}$ \\
\hline Tertiary sector & $z_{31}$ & $z_{32}$ & $\mathrm{z}_{33}$ & $\mathrm{y}_{3}$ & $x_{3}$ \\
\hline Value added & $v_{1}$ & $v_{2}$ & $v_{3}$ & & \\
\hline Resources in total & $x_{1}$ & $x_{2}$ & $x_{3}$ & & \\
\hline
\end{tabular}

Source: Own table according to CSO (2014) and Rojíček (2007)

\section{Tab. 2: Input coefficients matrix}

\begin{tabular}{l|c|c|c}
\multirow{2}{*}{\multicolumn{1}{c}{ Inputs/Outputs }} & \multicolumn{3}{c}{ Intermediate consumption } \\
\cline { 2 - 4 } & Primary sector & Secondary sector & Tertiary sector \\
\hline Primary sector & $\mathrm{a}_{11}=\mathrm{z}_{11} / \mathrm{x}_{1}$ & $\mathrm{a}_{12}=\mathrm{z}_{12} / \mathrm{x}_{2}$ & $\mathrm{a}_{13}=\mathrm{z}_{13} / \mathrm{x}_{3}$ \\
\hline Secondary sector & $\mathrm{a}_{21}=\mathrm{z}_{21} / \mathrm{x}_{1}$ & $\mathrm{a}_{22}=\mathrm{z}_{22} / \mathrm{x}_{2}$ & $\mathrm{a}_{23}=\mathrm{z}_{23} / \mathrm{x}_{3}$ \\
\hline Tertiary sector & $\mathrm{a}_{31}=\mathrm{z}_{31} / \mathrm{x}_{1}$ & $\mathrm{a}_{32}=\mathrm{z}_{32} / \mathrm{x}_{2}$ & $\mathrm{a}_{33}=\mathrm{z}_{33} / \mathrm{x}_{3}$ \\
\hline
\end{tabular}

Source: Own table based on Impacts 08 (2008)

$A_{i j}=z_{i j} / x_{j}$ (see Tab. 2). The input coefficients matrix expresses the view of a customer (demand-oriented $\mathrm{I}-\mathrm{O}$ model). These input coefficients, or direct consumption coefficients, indicate how individual intermediate products contribute to the production of one product of a particular sector and show the so-called "backward linkages" (Rojíček, 2007; Impacts08, 2008).

Table 2 shows normalization of transactions table. Here $a_{i j}$ indicates how much of one product of industry $j$ is created by the input from the $i$ industry. After obtaining the input coefficients matrix that actually shows direct consumption, it is necessary to include indirect consumption as well. The procedure is as follows: the matrix of direct consumption coefficients is subtracted from the unit matrix and the inversion matrix is created from the resulting matrix. Such a compiled matrix is called a matrix of comprehensive consumption coefficients and the coefficients themselves are called output multipliers. If the values in individual columns of the matrix are added together, the output multipliers for the entire industry are obtained.

These are multipliers of type 1 . To calculate the multipliers of type 2 , it is necessary to include households into the matrix of direct consumption coefficients, and thus another row ("wages and salaries") and another column ("final consumption expenditure of households") are added. The specific steps for calculating these multipliers are stated, for example, in the methodology of The Scottish Government (2011) or the Australian Bureau of Statistics (1995). In this article, however, multipliers of type 2 will not be used at all, because there are not enough data for calculating them for the regional tables. Multipliers (either type 1 or 2) calculated by the method described above are called output multipliers and indicate by how much the production of the entire economy (or more precisely the region) will increase if there is an increase in demand for the production of industry $i$ by one unit. However, according to Raabová (2010), these multipliers can often be considerably distorted (all intermediate consumption is included, and thus if a product is only traded in it will incorrectly be included in the calculation of the multiplier several times). Other types of multipliers help to solve this issue: the gross value added multiplier, the income multiplier and the employment multiplier. 
Therefore, the value added multiplier (gross) does not include intermediate consumption. It indicates by how much the gross value added increases in the economy if the demand for the output of the selected sector increases by one unit. To calculate the value added multipliers, it is necessary to know the value of the coefficient vector $g$, which indicates how the gross value added participates in the production of one output unit of a particular sector (it is the row vector of added value from the normalized SIOT). This vector is then multiplied by the Leontief inverse matrix in order to include other rounds of consumption and the vector of value added multipliers for individual sectors is obtained (Economic Impacts, 2011).

Income multiplier can be calculated similar way. It shows by how much the income from wages, salaries and social transfers, i.e. "compensation of employees" (the sum of "wages and salaries" and "employers' social contributions" from the published SIOT), will increase in the whole economy if the demand for the production of selected industry increases by one unit. To calculate it, the vector of coefficients $i$, specifying how the compensation for employees participates in the production of one output unit in a particular sector (corresponding vector from the normalized SIOT), is needed. This vector is multiplied by the Leontief inverse matrix again, and the income multipliers for individual sectors are obtained (Australian Bureau of Statistics, 1995).

It is also possible to calculate the same way employment multipliers using the vector e. However, this one cannot be obtained from the standardized SIOT, but from other sources, as it is calculated as a quotient of the number of persons employed in the sector to the production generated by the respective sector (Australian Bureau of Statistics, 1995). These multipliers indicate how many new jobs will be created throughout the economy if the demand for the output of selected industries increases by one unit.

\section{Regional Multipliers}

According to Fjedlsted (1990), multipliers calculated for a large area cannot be applied to a small area. It is due to the logical assumption that regional multipliers are lower than the national ones because regional economies, unlike national economies, tend to be more open (there are higher leakages), as, for example, there are fewer suppliers and employees in the smaller area and very often external resources must be used (Macháček et al., 2013). Therefore, if the tables calculated for the whole country were used for the calculation of multipliers of lower regional levels, the resulting data would be greatly overestimated. Thus, if the I-O analysis has to be made for a smaller area than the entire country, i.e. for the national level (for which the SIOT are regularly published), it is necessary to use a suitable method to compile the appropriate tables.

Since the development of I-O models, many researchers have begun to deal with the regional I-O models. One of the first ones was already mentioned Isard (1953), but as Hewings and Jensen (1986, p. 302) mentioned, his model "has rarely been implemented empirically". This issue was also dealt with by Morisson and Smith (1974), who identified two basic approaches to creating regional I-O tables. They state that analysts can either "collect all or some of the data through empirical survey, or can attempt to produce an I-O table from the available published statistics" (Morisson \& Smith, 1974, p. 2). They also specify that the first option will be the most expensive and the second the least accurate.

Hewings and Jensen (1986) have given a more detailed overview of different methods for compiling regional tables, which they have divided into four basic approaches: commoditybased methods, survey-based methods, nonsurvey methods and hybrid approaches. The first approach can be applied in very rare cases where there are detailed data on inputs and outputs at the regional level for every sector available. In this case, one can construct regional $\mathrm{I}-\mathrm{O}$ tables using the same methods as for the national ones. The second is the surveybased method, which, in order to construct I-O tables, uses primary data obtained through questionnaires completed in businesses, organizations and from other sources, and from them buying and selling behaviour formulae are derived. These data are then processed and the respective $\mathrm{I}-\mathrm{O}$ tables are derived from them. The method is very demanding in terms of resources and time. The third are the so-called "non-survey methods", and they are based on deriving regional tables from the national ones. Hewings and Jensen (1986) define three basic approaches to their deriving: using commodity balance tables, the quotient 
approach and the iterative approach. The fourth and most recent approach to compiling the regional tables is a hybrid approach. It uses the attributes of both non-survey and surveybased methods. Using these methods, the preliminary table is first constructed, into which the survey results, i.e. primary or preferred data, are subsequently included. There are several methods of the hybrid approach and their characteristics are presented by Hewings and Jensen (1986). One of them is the GRID method (Generation of Regional Input-Output Table), which was successfully used in the Czech conditions (Bednaříková, 2012). The method was introduced by Jensen et al. (1979) and consists of several steps. At first, it is necessary to calculate the national technical coefficients from the national table and then to recalculate the national coefficients into the regional ones using location quotients. Subsequently, more specific data are entered (e.g. from questionnaires) and very often the aggregation of data for sectors occurs.

Having considered all possible alternatives for calculating the regional $\mathrm{I}-\mathrm{O}$ tables, the most appropriate way to calculate the regional table for the Pilsen region has been the one using some of the recommendations for the GRID method, but also taking into account the fact that the conversion should primarily be based on the use of location quotients, namely the latest quotient FLQ.

The specific calculation procedure will be described according to contemporary authors, such as Flegg and Webber (1997), Golemanova and Kuhar (2007), Kowalewski (2012), Bendaříková (2012) and Flegg and Tohmo (2013), as well as according to authors who introduced these methods to the world or who have actively dealt with them after their development, e.g. Morrison and Smith (1974) or Round (1978). The calculation of regional SIOT consists of several basic steps (they will be described according to Golemanova and Kuhar (2007)). The first step is the adjustment of the national I-O table, the next one is the computation of the regional direct requirement matrix, aggregation of regional sectors and the computation of the complete regional I-O tables.

According to Golemanova and Kuhar (2007), the adjustment of the national I-O table means deleting the intra-sectoral flows in the main diagonal of the national SIOT, because the transactions that appear to be intra-sectoral at the national level will become imports at the regional level in most cases and their entering in the table could cause an overestimation of the regional intermediate consumption. This premise has already been mentioned by Morrison and Smith (1974), who, however, have clarified that it may not always be applicable, especially for larger regions, where transactions within sectors may be expected. In smaller regions, these authors recommend to enter zeros into the principal diagonal of the direct requirements matrix, but only for some sectors (e.g. for the manufacturing and construction industries, but not for the services sector).

The next step in the calculation is computation of the regional direct requirement matrix. Here, location quotients, which convert the national coefficients into the regional ones, are used. Calculations of these quotients can be based on various indicators of economic activity (output, employment, sales, etc.), but it is difficult to find a scientific work that would use another criterion than employment (other data are not usually available). There are several types of quotients (see Morrison \& Smith, 1974), but the most commonly used ones are SLQ (Simple Location Quotient), CILQ (CrossIndustry Location Quotient) and FLQ (FleggWeber Location Quotient). The first two were commonly used in works from the seventies and the FLQ was introduced in the nineties. Thanks to these quotients it is possible to estimate regional trading coefficients that state "the proportion of regional requirements met by firms located within the region" (Flegg \& Webber, 1997, p. 796).

The methods using location quotients are based on assumptions that technologies do not differ at the national and regional levels (i.e. companies at national and regional levels use the same ratios of different inputs to produce individual outputs), but the technical coefficients do differ, namely to the extent to which goods and services are imported from other regions (proved by Flegg and Tohmo (2013)). Therefore, one can write that $a_{i j}=r_{i j}+m_{i j}$, where $a_{i j}$ is a national direct consumption coefficient, $r_{i j}$ is a regional direct consumption coefficient (input coefficient) and $m_{i j}$ is a regional import coefficient (Morrison \& Smith, 1974). Coefficient $r_{i j}$ can be defined as the amount of regional input $i$ consumed to produce one unit of regional gross output $j$ (Flegg \& Webber, 1997). Imports 
from other regions and from abroad are then expressed as coefficient $m_{i j}$.

This approach suggests that regional direct consumption coefficient must always be lower than or the same as the national direct consumption coefficient, i.e. $r_{i j} \leq a_{i j}$. Regional direct consumption coefficients are thus estimated as follows: $r_{i j}=a_{i j}{ }^{*} q_{i j}$ where $\mathrm{q}_{\mathrm{ij}}$ represents the modification of the national coefficient (Kowalewski, 2012). This $\mathrm{q}_{i j}$ can be made identitical with the above mentioned trading coefficient (marked $t_{i j}$ ), which expresses how much of the required inputs in the region can be provided by local businesses. This coefficient can range from $0 \leq \mathrm{t}_{\mathrm{ij}} \leq 1$ (Round, 1978) and the method of its calculation depends on the type of location quotient (general $q_{i j}$, or $t_{i j}$ is thus replaced by the selected quotient). The most commonly used and simplest one is SLQ, which is for the sector $i$ defined as follows:

$$
S L Q_{i}=\frac{E_{i}^{R} / E^{R}}{E_{i}^{N} / E^{N}}
$$

where $E_{i}^{R}$ is a regional employment in the sector $i, E^{R}$ is the total employment in the region, $E_{i}^{N}$ is the national employment in sector $i$ and $E^{N}$ is the total national employment. Thus, the indicator measures the concentration of the selected sector in the region in comparison with the level of a higher territorial unit (the country). Intuitively, it can be deduced that if $S L Q_{i}>1$, the sector is more concentrated in the analysed region than in the entire country and if $S L Q_{i}<1$ than it is less concentrated. These features may be used in the conversion of national input coefficients to the regional ones. If $S L Q_{i}>1$, it can be assumed that the sector in the region is able to meet the requirements of demand for its goods and services within the region and the regional direct consumption coefficient is thus equal to the national one $\left(r_{i j}=a_{i j}\right)$. The same applies if $S L Q_{i}=1$. However, if $S L Q_{i}<1$, then it can be assumed that the industry in the analysed region needs to import from other regions to be able to meet the requirements of demand for its products and services, and thus $r_{i j}=a_{i j}{ }^{*} S L Q_{i}$.

One of the first improvements of this quotient was CILQ, which reflects the supplydemand relations between sectors. The quotient compares the proportion of regional employment of the selling sector $i$ to the national one with the proportion of the regional employment of the buying sector $j$ to the national one. The formula takes the following form:

$$
C I L Q_{i j}=\frac{E_{i}^{R} / E_{i}^{N}}{E_{j}^{R} / E_{j}^{N}}
$$

where $E_{i}^{R}$ is the regional employment in sector $i, E_{i}^{N}$ is the national employment in sector $i, E_{i}^{R}$ is the regional employment in sector $j, E^{N}$ is the national employment in sector $j$. It is also possible to write:

$$
C I L Q_{i j}=\frac{S L Q_{i}}{S L Q_{j}}
$$

If CILQ > 1, it indicates that the regional selling sector $i$ is able to satisfy all the requirements of the regional buying sector $j$. In that case no modifications of national direct consumption coefficients are required and $r_{i j}=a_{i j}$. The same applies if CILQ $=1$ (if it is not in the diagonal - see below). If CILQ $<1$, then the regional selling sector $i$ is unable to meet all the requirements of the regional buying sector $j$ and imports are necessary. In this case, the national direct requirements coefficient must be modified as follows: $r_{\mathrm{ij}}=\mathrm{a}_{\mathrm{ij}}{ }^{*} \mathrm{CILQ} \mathrm{Q}_{\mathrm{ij}}$.

Using CILQ has its pitfalls, as stated by Morrison and Smith (1974). The first drawback is that this indicator does not reflect the relative size of the region in relation to the higher territorial unit. Another problem arises due to the construction of CILQ which equals one for all intra-sectoral transactions, so it is recommended to use the SLQ for calculations in the main diagonal of the matrix.

The last frequently used quotient is FLQ, which was introduced by Flegg and Weber in 1995 and modified in 1997 (Flegg \& Weber, 1997). The quotient is based on CILQ and takes the following form:

$$
\begin{array}{cc}
F L Q_{i j}=C I L Q_{i j} * \lambda^{*} & \text { for } \mathrm{i} \neq \mathrm{j} \\
F L Q_{i j}=S L Q_{i j} * \lambda^{*} & \text { for } \mathrm{i}=\mathrm{j}
\end{array}
$$

where $\lambda^{*}=\left[\log _{2}\left(1+E^{R} / E^{N}\right)\right]^{\delta}$.

The indicator thus includes not only the values of CILQ indicator, which reflects the inter-sectoral connections, but also takes into account the relative size of the region using $\lambda^{*}$, and avoids the disadvantages of CILQ. Thus is takes into account the relative size of both 
the supplying and the buying sectors (Flegg \& Weber, 1997).

Values of the parameter $\lambda^{*}$ can range from 0 to 1 and the parameter is dependent on both $E^{R} / E^{N}$ and the parameter $\delta$. The value of $\lambda^{*}$ increases with the size of the region $E^{R} / E^{N}$, and decreases with the growth of the parameter $\delta$. The parameter $\lambda^{*}$ expresses the need for imports (the higher the $\lambda^{*}$ is, the lower is the need for imports). The greatest need for imports logically arises in small regions. The exponent $\delta$ ranges from 0 to 1 and it is an element of flexibility. The value of $\delta$ also increases with the size of the region, but it also has an opposing effect on the value of $\lambda^{*}$. A higher value of $\delta$ reduces the value of $\lambda^{*}$ and there is a greater need for imports. In the rare case when $\delta=0$ and therefore $\lambda^{*}=1$, then FLQ $=$ CILQ. It is also true that when $\lambda^{*} \rightarrow 1$, also the $E^{R} \rightarrow E^{N}$ (Flegg \& Tohmo, 2013).

The choice of the parameter $\delta$ size is rather an empirical issue. Flegg and Tohmo (2013) in their work dealt with the evaluation of FLQ and then with the determination of optimal values of $\delta$. Their work was based on comparing the results of already compiled regional tables by the survey-based method and tables compiled by them using FLQ. The authors have observed that the value of $\delta$ grows with the size of the region (the region's size is measured by its share in the national output) and $\delta=0.25$ appeared to be the best value. The authors have also developed a regression equation (Flegg \& Tohmo, 2013, p. 713), which is used to calculate the value of $\delta$ :

$$
\begin{aligned}
& \ln \delta=-1.8379+0.33195 \ln R+ \\
& +1.5834 \ln P-2.8812 \ln I+e
\end{aligned}
$$

where $R$ is the size of the region, measured as a share of output or employment of the region and of the whole country (in percentage), $P$ is an estimate of the regional propensity to import (based on the survey) divided by the average propensity to import of all other regions, $I$ is an estimate of the average regional intermediate consumption, including region imports (based on the survey) divided by the corresponding national value and $e$ is a residue. However, the authors themselves realize that to obtain $I$ and $P$ is quite complicated, and therefore they propose analysts to proceeded with the assumption that $I=P=1$, which will lead to:

$$
\ln \delta=-1.8379+0.33195 \ln R
$$

This approach brings better results as opposed to just picking the "best" value of $\delta=0.25$.

The same conditions for recalculating the national input coefficients into the regional ones apply for this indicator. If FLQ $>1$, then the regional sectorial supply (sector $i$ ) is sufficient to meet the demand requirements of the buyer sector $j$ and the national input coefficient is equal to the regional one. The same applies, even if $F L Q=1$. In the case that $F L Q<1$, the supply of the seller sector $i$ is insufficient to meet demand requirements of the buyer sector $j$ and therefore some products must be imported. Then it is necessary to reduce the corresponding national technical coefficients as follows: $r_{i j}=a_{i j}{ }^{*} F L Q_{i j}$.

Many works have dealt with the choice of the appropriate quotient. As already suggested by Round (1978), the trading coefficient should be a function of three variables: the relative size of the selling sector $i$, the relative size of the buying sector $j$ and the relative size of the region. The first variable is represented by the relation $E_{i}^{R} / E_{i}^{N}$, the second one by $E_{j}^{R} / E_{i}^{N}$ and the third one by $E^{R} / E^{N}$. It is obvious that SLQ takes into account the first and third ones and vice versa CILQ considers the first and second ones, but FLQ takes into account all three of them. FLQ as the most accurate method is endorsed by a number of works (Tohmo, 2004; Bonfiglio \& Chelli, 2008; Kowalewski, 2012). Moreover, Flegg and Tohmo (2013) believe that it is a quotient suitable for use in a hybrid model of non-survey methods. Therefore, FLQ is also used in this paper.

Once the quotients are calculated and the national direct consumption matrix is converted to the regional one, also sectors with zero employment must be excluded. According to Golemanova and Kruhar (2007), the third step is an aggregation of regional sectors. It is appropriate to combine some small and unimportant sectors (with little economic activity, i.e. employment) with others that have similar technology. The final step (Golemanova \& Kruhar, 2007) is the calculation of the complete regional I-O tables, i.e. the conversion of the regional input coefficients table into the product-by-product table, expressed in prices. For this purpose, it is necessary to convert the obtained direct consumption coefficients matrix into monetary flows.

To calculate the monetary flows, it is necessary to obtain a vector of total regional 
resources that can be estimated using the employment proportion and SLQ (if its calculation is based on employment) from the national data table. If for any sector SLQ > 1 applies, it can be concluded that the sector is appropriately represented in the region and employment proportions (in this case, the proportions of the number of people employed in individual sectors of the region to the number of people employed in individual sectors of the entire country) are suitable to estimate the regional output (by multiplying the national outputs of individual sectors by the respective employment proportions). If, however, SLQ $<1$ and the sector is not represented in the region to large extent, the sector outputs must be adapted (by multiplying the aforementioned value by the respective SLQ).

In order to calculate the total I-O tables, it is also necessary to deduce several more items both on the input and output sides (e.g. final consumption expenditure, exports, imports, gross value added, etc.). The intermediate consumption is calculated by multiplying the respective coefficients of direct consumption and total resources. Other higher groups in SIOT may be derived as the difference between the total regional output/input of sectors and the overall regional intermediate consumption of sectors. The remaining items are derived either by entering some superior data, or by estimate using the employment proportion to SLQ and calculating the others as residual. However, most of these items of the last step are not needed at all to calculate regional multipliers.

\section{Computation of Regional SIOT}

The SIOT, published for the Czech Republic (at the time the paper was processed, the latest version was for 2010), are divided into 82 sectors (or more precisely groups) and for the purpose of calculating the regional SIOT it was first necessary to aggregate data from the original 82 groups into 19 sections (this is the CZ-CPA classification, where each section contains several groups - it is therefore an aggregation of data at a higher hierarchical level), namely due to the fact that data concerning the employment structure must be available in the same structure as is the structure of SIOT in order to convert the national tables into the regional ones. Unfortunately, the data relating to the employment structure of the Pilsen Region (and other regions) are available only for 19 sections of CZ-CPA, and therefore the SIOT data had to be aggregated in this way. This fact naturally limits the number of resulting multipliers, which will be computed only for 19 sectors.

It was further decided that the Pilsen Region could expect intra-sector transactions,

\section{Tab. 3: Values of SLQ for industries in the Pilsen Region}

\begin{tabular}{|c|c|c|c|c|c|}
\hline Agriculture, forestry and fishing & A & 1.60398 & Information and communication & $\mathbf{J}$ & 0.50504 \\
\hline Mining and quarrying & B & 0.55496 & Financial and insurance activities & $\mathbf{K}$ & 0.75554 \\
\hline Manufacturing & C & 1.19583 & Real estate activities & $\mathbf{L}$ & 0.76215 \\
\hline $\begin{array}{l}\text { Electricity, gas, steam and air } \\
\text { conditioning supply }\end{array}$ & D & 0.84098 & $\begin{array}{l}\text { Professional, scientific and } \\
\text { technical activities }\end{array}$ & M & 0.70320 \\
\hline $\begin{array}{l}\text { Water supply, sewage, waste } \\
\text { management, and rem. act. }\end{array}$ & $\mathbf{E}$ & 1.07581 & $\begin{array}{l}\text { Administrative and support } \\
\text { service activities }\end{array}$ & $\mathbf{N}$ & 1.01377 \\
\hline Construction & $\mathbf{F}$ & 0.87704 & $\begin{array}{l}\text { Public administration and } \\
\text { defence; obligatory social security }\end{array}$ & 0 & 0.97823 \\
\hline $\begin{array}{l}\text { Wholesale and retail trade; repair } \\
\text { of motor vehicles }\end{array}$ & G & 0.96085 & Education & $\mathbf{P}$ & 0.99973 \\
\hline Transportation and storage & $\mathbf{H}$ & 0.88635 & $\begin{array}{l}\text { Human health and social work } \\
\text { activities }\end{array}$ & $\mathbf{Q}$ & 1.05784 \\
\hline $\begin{array}{l}\text { Accommodation and food service } \\
\text { activities }\end{array}$ & I & 0.90039 & Arts, entertainment and recreation & $\mathbf{R}$ & 1.30107 \\
\hline & & & Other service activities & $\mathbf{s}$ & 0.60654 \\
\hline
\end{tabular}

Source: Own calculations based on data from the Czech Statistical Office (2015a; 2015b) 
and therefore the intra-sectoral flows in the main diagonal of the national SIOT were not deleted. Subsequently, the direct consumption coefficients matrix was calculated by the standard method.

The obtained coefficients were then recalculated using the FLQ formula, which appeared to be the most accurate method. To do this, it was necessary to calculate also SLQ and CILQ.

The values of SLQ are shown in Table 3 . Where the value of SLQ is greater than 1 , the industry is more concentrated in the Pilsen Region than in the rest of the country.

Similar results can be observed also in the CILQ formula, though it is calculated for all combinations of sellers and buyers; however, due to the limited extent of the article, the results will not be presented.

The last quotient is FLQ, which is calculated using CILQ and the formula compiled by Flegg and Tohmo (2013) for the calculation of $\delta$ (the parameter $R$ was calculated using the employment proportion). The value of $R$ parameter for the Pilsen Region was $5.59 \%$ and consequently the value of $\delta$ parameter was 0.28 , which approaches the mentioned value of 0.25 that Flegg and Tohmo determined as the "best value" in their work (2013). Also the value of parameter $\lambda^{*}$ was determined -0.49 . The values of FLQ were determined using this parameter for the combination of all sectors. Not a single sector in the Pilsen Region showed zero employment, according to any measured quotient, and therefore no sector was deleted.

Table 4 gives the values of this quotient. Results greater than 1 are written in bold (sectors are marked by letters - see the names in Tab. 3). For example, the value of 1.4 for the industry $A / B$ means that the industry $A$ is able to satisfy the demands of the industry $B$ regionally. Conversely, the requirements of the industry A (which is, according to the SLQ, highly concentrated in the Pilsen Region) cannot be satisfied by any other industry only regionally. Other similar, logical relations, especially in terms of the behaviour of the least concentrated industries towards the most concentrated ones, can be traced in Table 3 and 4 .

\section{Tab. 4: Values of FLQ for industries in the Pilsen Region}

\begin{tabular}{|c|c|c|c|c|c|c|c|c|c|c|c|c|c|c|c|c|c|c|c|}
\hline & A & B & $C$ & D & $E$ & $F$ & G & $\mathrm{H}$ & I & $\mathbf{J}$ & K & L & M & $\mathrm{N}$ & 0 & $\mathbf{P}$ & $\mathbf{Q}$ & $\mathbf{R}$ & $\mathbf{S}$ \\
\hline A & 0.8 & 1.4 & 0.7 & 0.9 & 0.7 & 0.9 & 0.8 & 0.9 & 0.9 & 1.6 & 1.0 & 1.0 & 1.1 & 0.8 & 0.8 & 0.8 & 0.7 & 0.6 & 1.3 \\
\hline B & 0.2 & 0.3 & 0.2 & 0.3 & 0.3 & 0.3 & 0.3 & 0.3 & 0.3 & 0.5 & 0.4 & 0.4 & 0.4 & 0.3 & 0.3 & 0.3 & 0.3 & 0.2 & 0.4 \\
\hline C & 0.4 & 1.1 & 0.6 & 0.7 & 0.5 & 0.7 & 0.6 & 0.7 & 0.6 & 1.2 & 0.8 & 0.8 & 0.8 & 0.6 & 0.6 & 0.6 & 0.6 & 0.4 & 1.0 \\
\hline D & 0.3 & 0.7 & 0.3 & 0.4 & 0.4 & 0.5 & 0.4 & 0.5 & 0.5 & 0.8 & 0.5 & 0.5 & 0.6 & 0.4 & 0.4 & 0.4 & 0.4 & 0.3 & 0.7 \\
\hline$E$ & 0.3 & 0.9 & 0.4 & 0.6 & 0.5 & 0.6 & 0.5 & 0.6 & 0.6 & 1.0 & 0.7 & 0.7 & 0.7 & 0.5 & 0.5 & 0.5 & 0.5 & 0.4 & 0.9 \\
\hline $\mathbf{F}$ & 0.3 & 0.8 & 0.4 & 0.5 & 0.4 & 0.4 & 0.4 & 0.5 & 0.5 & 0.8 & 0.6 & 0.6 & 0.6 & 0.4 & 0.4 & 0.4 & 0.4 & 0.3 & 0.7 \\
\hline G & 0.3 & 0.8 & 0.4 & 0.6 & 0.4 & 0.5 & 0.5 & 0.5 & 0.5 & 0.9 & 0.6 & 0.6 & 0.7 & 0.5 & 0.5 & 0.5 & 0.4 & 0.4 & 0.8 \\
\hline H & 0.3 & 0.8 & 0.4 & 0.5 & 0.4 & 0.5 & 0.5 & 0.4 & 0.5 & 0.9 & 0.6 & 0.6 & 0.6 & 0.4 & 0.4 & 0.4 & 0.4 & 0.3 & 0.7 \\
\hline I & 0.3 & 0.8 & 0.4 & 0.5 & 0.4 & 0.5 & 0.5 & 0.5 & 0.4 & 0.9 & 0.6 & 0.6 & 0.6 & 0.4 & 0.4 & 0.4 & 0.4 & 0.3 & 0.7 \\
\hline $\mathbf{J}$ & 0.2 & 0.4 & 0.2 & 0.3 & 0.2 & 0.3 & 0.3 & 0.3 & 0.3 & 0.2 & 0.3 & 0.3 & 0.4 & 0.2 & 0.3 & 0.2 & 0.2 & 0.2 & 0.4 \\
\hline K & 0.2 & 0.7 & 0.3 & 0.4 & 0.3 & 0.4 & 0.4 & 0.4 & 0.4 & 0.7 & 0.4 & 0.5 & 0.5 & 0.4 & 0.4 & 0.4 & 0.3 & 0.3 & 0.6 \\
\hline $\mathrm{L}$ & 0.2 & 0.7 & 0.3 & 0.4 & 0.3 & 0.4 & 0.4 & 0.4 & 0.4 & 0.7 & 0.5 & 0.4 & 0.5 & 0.4 & 0.4 & 0.4 & 0.4 & 0.3 & 0.6 \\
\hline $\mathbf{M}$ & 0.2 & 0.6 & 0.3 & 0.4 & 0.3 & 0.4 & 0.4 & 0.4 & 0.4 & 0.7 & 0.5 & 0.5 & 0.3 & 0.3 & 0.4 & 0.3 & 0.3 & 0.3 & 0.6 \\
\hline $\mathbf{N}$ & 0.3 & 0.9 & 0.4 & 0.6 & 0.5 & 0.6 & 0.5 & 0.6 & 0.5 & 1.0 & 0.7 & 0.6 & 0.7 & 0.5 & 0.5 & 0.5 & 0.5 & 0.4 & 0.8 \\
\hline 0 & 0.3 & 0.9 & 0.4 & 0.6 & 0.4 & 0.5 & 0.5 & 0.5 & 0.5 & 0.9 & 0.6 & 0.6 & 0.7 & 0.5 & 0.5 & 0.5 & 0.5 & 0.4 & 0.8 \\
\hline $\mathbf{P}$ & 0.3 & 0.9 & 0.4 & 0.6 & 0.5 & 0.6 & 0.5 & 0.6 & 0.5 & 1.0 & 0.6 & 0.6 & 0.7 & 0.5 & 0.5 & 0.5 & 0.5 & 0.4 & 0.8 \\
\hline$Q$ & 0.3 & 0.9 & 0.4 & 0.6 & 0.5 & 0.6 & 0.5 & 0.6 & 0.6 & 1.0 & 0.7 & 0.7 & 0.7 & 0.5 & 0.5 & 0.5 & 0.5 & 0.4 & 0.9 \\
\hline $\mathbf{R}$ & 0.4 & 1.1 & 0.5 & 0.8 & 0.6 & 0.7 & 0.7 & 0.7 & 0.7 & 1.3 & 0.8 & 0.8 & 0.9 & 0.6 & 0.6 & 0.6 & 0.6 & 0.6 & 1.0 \\
\hline $\mathbf{S}$ & 0.2 & 0.5 & 0.2 & 0.4 & 0.3 & 0.3 & 0.3 & 0.3 & 0.3 & 0.6 & 0.4 & 0.4 & 0.4 & 0.3 & 0.3 & 0.3 & 0.3 & 0.2 & 0.3 \\
\hline
\end{tabular}


The coefficient matrix of national direct consumption (inputs) was multiplied by the identified FLQs, which resulted in the matrix of regional coefficients.

Subsequently, the aggregation of sectors with little economic activity with those using similar technology should be performed. Given the already low number of sectors that were aggregated at the beginning of the calculations, this step was skipped and no further aggregation was carried out.

The last step was to calculate the entire regional I-O tables. The SLQ coefficients and employment proportions, by which the total resources, the gross value added and wages and salaries were estimated, were used for this calculation. Individual items of intermediate consumption (as well as the total intermediate

\section{Tab. 5: Regional input-output table for the Pilsen Region for 2010 (mil. CZK) - Part 1}

\begin{tabular}{|c|c|c|c|c|c|c|c|c|c|c|}
\hline & A & B & C & D & $\mathbf{E}$ & $\mathbf{F}$ & G & H & 1 & $J$ \\
\hline A & 1,206 & 6 & 4,242 & 27 & 2 & 15 & 134 & 6 & 405 & 0 \\
\hline B & 12 & 18 & 1,875 & 1,136 & 8 & 110 & 1 & 8 & 0 & 0 \\
\hline C & 1,766 & 213 & 62,064 & 641 & 590 & 3,677 & 3,069 & 1,449 & 1,022 & 331 \\
\hline D & 57 & 27 & 1,613 & 1,266 & 48 & 85 & 195 & 351 & 114 & 29 \\
\hline$E$ & 33 & 13 & 579 & 67 & 675 & 59 & 37 & 14 & 28 & 0 \\
\hline$F$ & 53 & 17 & 578 & 53 & 120 & 6,096 & 104 & 454 & 57 & 11 \\
\hline G & 375 & 31 & 6,060 & 89 & 272 & 461 & 2,465 & 516 & 215 & 127 \\
\hline $\mathrm{H}$ & 90 & 146 & 1,698 & 404 & 47 & 222 & 857 & 2,729 & 23 & 48 \\
\hline I & 11 & 2 & 54 & 11 & 8 & 96 & 123 & 133 & 43 & 13 \\
\hline $\mathrm{J}$ & 11 & 1 & 258 & 15 & 8 & 43 & 157 & 90 & 19 & 350 \\
\hline $\mathrm{K}$ & 81 & 12 & 550 & 63 & 38 & 240 & 342 & 386 & 33 & 19 \\
\hline$L$ & 21 & 1 & 183 & 14 & 62 & 195 & 916 & 115 & 207 & 86 \\
\hline M & 89 & 13 & 1,040 & 28 & 80 & 2,168 & 744 & 79 & 87 & 78 \\
\hline $\mathrm{N}$ & 24 & 17 & 555 & 19 & 71 & 338 & 546 & 352 & 130 & 97 \\
\hline 0 & 16 & 2 & 31 & 7 & 18 & 13 & 1 & 27 & 0 & 2 \\
\hline $\mathbf{P}$ & 5 & 0 & 21 & 8 & 2 & 7 & 24 & 22 & 1 & 10 \\
\hline $\mathbf{Q}$ & 0 & 0 & 13 & 0 & 1 & 0 & 3 & 3 & 2 & 0 \\
\hline$R$ & 0 & 0 & 3 & 0 & 2 & 0 & 1 & 1 & 21 & 1 \\
\hline$S$ & 2 & 0 & 47 & 0 & 1 & 8 & 78 & 24 & 19 & 6 \\
\hline $\begin{array}{l}\text { Intermediate consumption } \\
\text { (basic prices) }\end{array}$ & 3,851 & 518 & 81,465 & 3,847 & 2,053 & 13,832 & 9,796 & 6,759 & 2,425 & 1,208 \\
\hline Wages and salaries & 2,351 & 229 & 19,217 & 413 & 833 & 3,946 & 7,783 & 3,560 & 1,298 & 816 \\
\hline Employers' social contributions & \multirow{6}{*}{2,834} & \multirow{6}{*}{482} & \multirow{6}{*}{33,011} & \multirow{6}{*}{5,137} & \multirow{6}{*}{1,682} & \multirow{6}{*}{8,093} & \multirow{6}{*}{11,314} & \multirow{6}{*}{6,234} & \multirow{6}{*}{2,422} & \multirow{6}{*}{1,888} \\
\hline Other taxes on production & & & & & & & & & & \\
\hline Other subsidies on production & & & & & & & & & & \\
\hline Consumption of fixed capital & & & & & & & & & & \\
\hline Operating surplus, net & & & & & & & & & & \\
\hline Mixed income, net & & & & & & & & & & \\
\hline Value added, gross & 5,185 & 711 & 52,229 & 5,550 & 2,515 & 12,039 & 19,097 & 9,795 & 3,719 & 2,704 \\
\hline Output (basic prices) & 9,037 & 1,229 & 133,694 & 9,397 & 4,568 & 25,871 & 28,892 & 16,553 & 6,144 & 3,912 \\
\hline Import & 10,304 & 3,365 & 209,714 & 6,180 & 2,940 & 16,087 & 11,882 & 10,371 & 3,645 & 1,955 \\
\hline Total resources & 19,340 & 4,594 & 343,408 & 15,578 & 7,508 & 41,957 & 40,775 & 26,924 & 9,790 & 5,867 \\
\hline
\end{tabular}




\begin{tabular}{|c|c|c|c|c|c|c|c|c|c|}
\hline & $\mathrm{K}$ & $L$ & $M$ & $\mathbf{N}$ & 0 & $P$ & $\mathbf{Q}$ & $\mathbf{R}$ & $S$ \\
\hline A & 0 & 2 & 8 & 56 & 0 & 0 & 8 & 30 & 3 \\
\hline B & 0 & 0 & 2 & 2 & 4 & 3 & 0 & 0 & 0 \\
\hline C & 187 & 951 & 793 & 456 & 220 & 162 & 1,406 & 207 & 116 \\
\hline D & 68 & 223 & 34 & 9 & 157 & 120 & 140 & 41 & 25 \\
\hline E & 1 & 38 & 11 & 52 & 46 & 16 & 35 & 11 & 7 \\
\hline$F$ & 40 & 645 & 458 & 25 & 374 & 55 & 120 & 52 & 5 \\
\hline G & 81 & 166 & 300 & 367 & 42 & 23 & 197 & 71 & 48 \\
\hline $\mathrm{H}$ & 173 & 21 & 78 & 385 & 129 & 19 & 35 & 24 & 21 \\
\hline I & 14 & 76 & 102 & 210 & 62 & 33 & 84 & 34 & 17 \\
\hline $\mathbf{J}$ & 170 & 30 & 183 & 47 & 140 & 47 & 24 & 43 & 19 \\
\hline$K$ & 733 & 682 & 271 & 170 & 78 & 39 & 71 & 72 & 27 \\
\hline$L$ & 158 & 471 & 269 & 65 & 124 & 102 & 77 & 147 & 24 \\
\hline M & 199 & 174 & 1,496 & 102 & 273 & 63 & 60 & 74 & 17 \\
\hline $\mathbf{N}$ & 136 & 255 & 150 & 973 & 365 & 35 & 70 & 150 & 20 \\
\hline 0 & 13 & 4 & 7 & 6 & 119 & 1 & 8 & 9 & 3 \\
\hline $\mathbf{P}$ & 36 & 18 & 46 & 6 & 73 & 224 & 7 & 2 & 3 \\
\hline $\mathbf{Q}$ & 1 & 4 & 1 & 1 & 8 & 0 & 127 & 2 & 1 \\
\hline $\mathbf{R}$ & 0 & 15 & 5 & 3 & 1 & 0 & 3 & 327 & 30 \\
\hline $\mathrm{S}$ & 37 & 9 & 12 & 8 & 0 & 6 & 41 & 14 & 44 \\
\hline $\begin{array}{l}\text { Intermediate consumption } \\
\text { (basic prices) }\end{array}$ & 2,046 & 3,785 & 4,225 & 2,943 & 2,217 & 948 & 2,512 & 1,313 & 430 \\
\hline Wages and salaries & 1,259 & 11 & 2,248 & 1,890 & 6,029 & 4,431 & 4,525 & 827 & 285 \\
\hline Employers' social contributions & \multirow{6}{*}{4,114} & \multirow{6}{*}{10,355} & \multirow{6}{*}{3,831} & \multirow{6}{*}{2,311} & \multirow{6}{*}{6,227} & \multirow{6}{*}{3,475} & \multirow{6}{*}{3,979} & \multirow{6}{*}{1,597} & \multirow{6}{*}{663} \\
\hline Other taxes on production & & & & & & & & & \\
\hline Other subsidies on production & & & & & & & & & \\
\hline Consumption of fixed capital & & & & & & & & & \\
\hline Operating surplus, net & & & & & & & & & \\
\hline Mixed income, net & & & & & & & & & \\
\hline Value added, gross & 5,374 & 10,367 & 6,078 & 4,202 & 12,256 & 7,906 & 8,504 & 2,425 & 948 \\
\hline Output (basic prices) & 7,420 & 14,152 & 10,303 & 7,145 & 14,473 & 8,854 & 11,016 & 3,738 & 1,378 \\
\hline Import & 3,250 & 3,405 & 6,366 & 5,347 & 3,716 & 1,514 & 3,370 & 2,498 & 329 \\
\hline Total resources & 10,670 & 17,557 & 16,669 & 12,492 & 18,189 & 10,368 & 14,387 & 6,236 & 1,707 \\
\hline
\end{tabular}

Source: Own calculations based on data from the Czech Statistical Office (2015a, 2015b)

consumption for the sectors) were calculated by multiplying the respective coefficients of direct consumption and overall resources. Other items were calculated as a residue (the outputs side was not calculated, because its values are not required for further calculations of input coefficients and output multipliers). When comparing the results of the regional table to the national table, it was clear that in sectors where the direct consumption coefficient declined, the imports of goods increased correspondingly, which confirms the basic assumption of the location quotients' use. The final form of the I-O regional table is shown in Table 5, where again only letters are used for marking of each sector. 


\section{Sector Multipliers Related to the Culture}

The last stage of the calculations was the computation of individual types of multipliers, i.e. the multipliers of output, gross value added, income, and employment. The values of multipliers are estimated using appropriate vectors (see section 2). In the case of the gross value added and income multiplier, these vectors are calculated from the regional SIOT, i.e. originally from the national SIOT using the appropriate SLQ and employment proportion. It is evident from the calculation principle that the obtained vectors are not very accurate when compared with reality (unfortunately, the real data are not available), and therefore the resulting multipliers must be approached very carefully.

Tab. 6: The values of chosen regional multipliers for the Pilsen Region in $\mathbf{2 0 1 0}$

\begin{tabular}{|c|c|c|c|c|c|c|}
\hline \multirow[t]{2}{*}{$\begin{array}{c}\text { Type of multiplier/ } \\
\text { sector }\end{array}$} & $\begin{array}{l}\text { Wholesale } \\
\text { and retail } \\
\text { trade; repair } \\
\text { of mot. veh. }\end{array}$ & $\begin{array}{c}\text { Transpor- } \\
\text { tation and } \\
\text { storage }\end{array}$ & $\begin{array}{l}\text { Accommo- } \\
\text { dation and } \\
\text { food service } \\
\text { activities }\end{array}$ & $\begin{array}{l}\text { Arts, enter- } \\
\text { tainment and } \\
\text { recreation }\end{array}$ & \multirow[t]{2}{*}{$\begin{array}{c}\text { The highest } \\
\text { value }\end{array}$} & \multirow[t]{2}{*}{$\begin{array}{c}\text { The lowest } \\
\text { value }\end{array}$} \\
\hline & G & $\mathrm{H}$ & 1 & $\mathbf{R}$ & & \\
\hline Production & 1.31 & 1.33 & 1.32 & 1.27 & \begin{tabular}{|l|} 
Construction: \\
1.45
\end{tabular} & Education: 1.12 \\
\hline Gross value added & 0.57 & 0.47 & 0.47 & 0.49 & \begin{tabular}{|l} 
Education: \\
0.81
\end{tabular} & \begin{tabular}{|l} 
Mining and \\
quarrying: 0.20 \\
\end{tabular} \\
\hline Income & 0.29 & 0.22 & 0.20 & 0.22 & \begin{tabular}{|l} 
Education: \\
0.59
\end{tabular} & \begin{tabular}{|l|} 
Real estate \\
activities: 0.03
\end{tabular} \\
\hline Employment & 0.93 & 0.77 & 1.11 & 1.12 & $\begin{array}{l}\text { Education: } \\
1.67\end{array}$ & $\begin{array}{l}\text { Mining and } \\
\text { quarrying: } 0.20\end{array}$ \\
\hline
\end{tabular}

Source: Own calculations based on data from the Czech Statistical Office (2015a, 2015b)

Output and employment multipliers are thus the most accurate ones from the regional multipliers and the others should be used very carefully.

The values of individual multipliers are shown in Table 6.

Effects of culture are best expressed by the $\mathrm{R}$ sector called "Arts, entertainment and recreation," but others with similar effects are also shown in the table. The $G$ sector is given because of retail trade, which includes e.g. purchases of food, fuels and other goods related to travel. The $\mathrm{H}$ sector is related to the public transport (buses, trains or planes) and, finally, there is the I sector that is connected with the accommodation of visitors and restaurant services for them. For clarity, there are also sectors with the highest and lowest values for the respective multipliers.

The values of output multipliers are above average (which is 1.28) for most sectors. For example, the value of 1.27 for the $R$ sector means that if visitors buy tickets to a cultural event in Pilsen (or elsewhere in the region) amounting to CZK 1 million, the production in the region will increase not only by one million, but through the further rounds of consumption also by another approx. CZK 270 thousand. Similarly, the other values of output multipliers may be interpreted. The highest value of the output multiplier in the Pilsen region can be observed for the Construction sector, where an increase in demand for production in this sector by of CZK 1 causes an increase in production of the entire region by CZK 1.45. As regards the analysed sectors, the multiplier for R sector, which represents "pure" cultural activities, has the lowest value of those four. That is logical, because culture does not have as many supplier-customer relations as the other selected sectors (especially in one region) and thus there is not such a big increase in production caused by other rounds of consumption. This is also proved by the sum of the consumption coefficients for each of these sectors which is, in the case of $R$ sector, 
the lowest of those four (R: $0.21, \mathrm{G}: 0.24, \mathrm{H}$ : 0.25 , I: 0.25 ). The multipliers of gross value added express an increase of gross added value in the case of an increase in demand for production in a particular sector by one unit. Their values are rather below-average (the average is 0.51) in the Pilsen Region, except for the $G$ industry. Yet, these values are not negligible, especially when compared with the lowest value showed by the sector of Mining and quarrying (0.20). For instance, the value of 0.49 for the $\mathrm{R}$ industry means that ticket purchases amounting to CZK 1 million will bring the gross added value amounting to CZK 490 thousand to the region (these are wages and salaries, employers' social contributions, net taxes on production, consumption of fixed capital, etc.) This value is the second highest regarding analysed sectors (first is sector $G$ ) which indicates strong representation of workforce in this sector. Already mentioned sector $G$ has even higher value than is the value of total average, thus it has the biggest potential (from analysed sectors) to influence the regional gross value added in case of increased demand. Another is the income multiplier, which is focused solely on wage compensation (i.e. wages and salaries and employers' social contributions) and thus reflects an increase in this income due to an increase in demand for production of a particular sector by one unit. In this case, the values of selected sectors are slightly below average (0.23), again except for the G sector. The "Education" sector shows the highest value and the sector called "Real estate activities" shows the lowest value (this low value seemed somewhat strange, but it comes from the national SIOT, where the value of Wages and Salaries is very low for this sector). The interpretation of results is similar to the previous ones: the value of 0.22 for the $R$ sector means that ticket purchases amounting to CZK 1 mil. will bring approximately extra CZK 220 thousand in wages and salaries to the region. These multipliers also reflect the representation of workforce in sectors and their values also increase and decrease the same way as the gross value added multipliers, because income is just one element of the gross value added.

The last type is the employment multiplier. Its value considerably differs for the selected sectors and reflects how many new jobs can be created in the economy as a result of an increase in demand for the particular industry output by one unit, or in this case, by CZK 1 million (the data in SIOT are given in millions of $\mathrm{CZK}$ ). The values of the $\mathrm{I}$ and $\mathrm{R}$ sectors were higher than 1 (i.e. an increase in demand for production of these industries amounting to CZK 1 mil. would create at least one job). In this case, the average is 0.87 , thus the value for sector $G$ is still above average. The lowest value in the Pilsen Region was recorded for the sector of Mining and quarrying and the highest value was recorded for the sector of Education.

Generally speaking, the multipliers of industries related to culture (even for the $R$ industry itself) show relatively good values ranging around the average and thus these industries tend to greatly affect the economy of the Pilsen Region. The size of the total economic effect however, depends on the amount of money that is spent in region for goods and services of these sectors. The estimation of this amount caused by the Pilsen ECoC 2015 project is the aim of the currently on-going research.

\section{Conclusion}

$\mathrm{I}-\mathrm{O}$ modelling is a tool that has been used to understand the relationships between sectors for more than half a century. This tool is constantly evolving, as is the purpose of its use. In this paper, it was used to indicate the economic importance of culture, especially in relation to the project of Pilsen ECoC 2015.

A crucial part of this paper was to compute regional I-O tables using the selected method. In the Czech Republic, there are not many scholars who would deal with these issues and, therefore, a great emphasis was placed on explaining the procedure in order to initiate a discussion on this topic.

Subsequently, the values of sector multipliers related to culture were calculated. These, when compared to the others, showed values around the average, which is quite surprising for the underestimated cultural sectors. It indicates the importance of culture and its potential to influence the economy of the Pilsen Region. However, it is important to realize that culture can only affect the economy of the region if it is a case of big events of at least nationwide, but ideally international scope. The values of multipliers always apply, but the impact differs if there is a demand for the sector services amounting to several thousands of CZK in the case of a small event, or if the demand amounts 
to a million of CZK as is the case of a big international festival. Another important factor is the origin of visitors. The less economic effect can be expected when the visitors are residents of the region, because they would spend their money in the region even without the existence of the event. Conversely, when the visitors are foreign tourists who would not come to the Czech Republic, or rather the Pilsen Region, without the existence of this event, the effects can be expected significant.

For events such as the European Capital of Culture 2015, the prerequisite is a high attendance, usually with a high proportion of foreign visitors as well. They spend their money not only on admission fees, but also on accommodation, meals, souvenirs and other services. Thus the great economic impact can be expected also in Pilsen (respectively the Pilsen Region). The fact that the main impacts are expected in the City of Pilsen, but not in the whole region for which multipliers are calculated, should not be seen as an error. Input-output analysis considers supplier-customer linkages within the whole region (including the city) and the results are not influenced by the fact, where the money was spent. Thus, although the money was spent in Pilsen, the suppliers of services and goods may be located outside the city, which affects the rest of the region. Usually, the economic impacts of cultural events are calculated even for the national level (e.g. Herrero et al., 2006).

At the moment when it is possible to determine the total spending of different groups of visitors in different sectors caused by the Pilsen ECoC 2015 project, the overall impact on the economy of the region may be calculated using the computed multipliers. These results can be compared with the funds spent on the coordination and organisation of the $\mathrm{ECoC}$ events and can help the city of Pilsen (which have financed most of the programme) to evaluate biggest events and chose which ones should be sustained and which should be cancelled. This process can also be applied repeatedly to assess the change in economic impact of selected events.

Economic effects of ECoCs can be very high, but they always depend on the type of cultural programme and its possibilities to attract visitors from other regions. In the history, there were some very successful ECoCs with great economic impacts (e.g. Liverpool
2008), but also less successful and smaller projects with no long term impacts (e.g. Maribor 2012). Great impacts are mainly caused by the investments into the local cultural and recreational infrastructure and partly by elaborated cultural programme that continuous afterwards. I-O analysis used in this paper was already applied for evaluation of few former ECoCs (e.g. Salamanca 2002, Liverpool 2008, Maribor 2012). Methodologies were similar, but unfortunately based on multipliers derived from SIOT that were published by the local statistical offices for a large area (country). The non-existence of SIOT for smaller regions is seen as the biggest methodological problem when evaluating ECoC using $\mathrm{I}-\mathrm{O}$ analysis. The methodology presented in this paper shows the possible way to resolve that problem.

Pilsen ECoC 2015 made some big investments (e.g. new theatre) and created cultural programme that was seen by a large number of visitors. Together with the high values of calculated multipliers, it is clear that the economic impact of the project will be significant.

This work was supported by the research project SGS 2015-004 entitled "Research impact of the flagship projects on the economic development of cities and regions on the example of the European capitals of culture" at the University of West Bohemia.

\section{References}

Australian Bureau of Statistics. (1995). Information Paper: Australian National Accounts: Introduction to Input-Output Multipliers, 198990. Retrieved November 3, 2015, from http:// www.abs.gov.au/AUSSTATS/abs@.nsf/ DetailsPage/5246.01989-90?OpenDocument.

Bednaříková, Z. (2012). Ekonomický prínos zemědělství pro venkovskou ekonomiku: aplikace input-output analýzy. Politická ekonomie, 60(2), 265-285. doi:10.18267/j. polek.841.

Bonfiglio, A., \& Chelli, F. (2008). Assessing the behaviour of non-survey methods for constructing regional input-output tables through a Monte-Carlo simulation. Economic Systems Research, 20(3), 243-258. doi:10.1080/09535310802344315.

British Council. (2011). Mapping the Creative Industries: A toolkit. London: British Council. 
Czech Statistical Office. (2015a). Databáze národních účtů - tabulky dodávek a užití. Retrieved March 2, 2015, from http://apl.czso. cz/pll/rocenka/rocenkaout.dod_uziti.

Czech Statistical Office. (2015b). Trh práce v ČR - časové rady - 1993-2014. Retrieved September 8, 2015, from https:// www.czso.cz/csu/czso/204r-k-odvetvi-cinnostizamestnanych-v-nh-259ld5l6vg.

Decision No 445/2014/EU of the European Parliament and of the Council.

Dunlop, S., Galloway, S., Hamilton, C., \& Scullion, A. (2004). The economic impact of the cultural sector in Scotland. Retrieved March 4, 2015, from: http://christinehamiltonconsulting. com/wp-content/uploads/2011/10/EconomicImpact-Report.pdf.

Economic Impact. (2011). Analýza ekonomického dopadu. Pražské Quadriennale 2011, Príloha č. 1: Metodika pro výpočet ekonomických dopadů. Retrieved July 6, 2014, from http://www.pq.cz/cs/kompletni-text-studie. html.

European Commission. (2013). Komise vítá schválení programu Kreativní Evropa Evropským parlamentem. Retrieved July 16, 2014, from http://ec.europa.eu/ceskarepublika/ press/press_releases/13_1114_cs.htm.

European Commission. (2006). Study on the Economy of Culture in Europe. Retrieved July 18, 2016, from http://ec.europa.eu/culture/ library/studies/cultural-economy_en.pdf.

Fjedlsted, B. L. (1990). Regional InputOutput Multipliers: Calculation, Meaning, Use and Misuse. Utah Economic and Business Review, 50(10), 1-20.

Flegg, A. T., \& Webber, D. (1997). On the appropriate use of location quotients in generating regional input-output tables: Reply. Regional Studies, 31(8), 795-805. doi:10.1080/713693401.

Flegg, A. T., \& Tohmo, T. (2013). Regional Input-Output Tables and the FLQ Formula: A Case Study of Finland. Regional Studies. 47(5), 703-721. doi:10.1080/00343404.2011.5 92138.

Golemanova, A., \& Kuhar, A. (2007). InputOutput Model for the South-East Region in Bulgaria. Retrieved March 23, 2014, from http://www.daes.si/Konf07/Golemanova $\% 20$ Kuhar\%20DAES.pdf.

Hudec, O., \& Džupka, P. (2014). Cultureled regeneration through the young generation: Košice as the European Capital of Culture.
European Urban and Regional Studies, 23(3), 531-538. doi:10.1177/0969776414528724.

Herrero, L. C., Sanz, J. A., Devesa, M., \& del Barrio, A. M. (2006). The Economic Impact of Cultural Events A Case-Study of Salamanca 2002, European Capital of Culture. European Urban and Regional Studies, 13(1), 41-57. doi:10.1177/0969776406058946.

Hewings, G. J. D., \& Jensen, R. (1986). Regional, Interregional and Multiregional InputOutput Analysis. In Handbook of Regional and Urban Economics (pp. 295-355). doi:10.1016/ S1574-0080(00)80011-5.

Impacts 08. (2008). Considering the Economic Impacts of the 2008 European Capital of Culture: A Review on the Literature concerning "Economic Multiplier" Effects. Retrieved October 10, 2013, from http://www. liv.ac.uk/impacts08/publications/backgroundpapers/.

Impacts 08. (2010). Creating an Impact: Liverpool's experience as European Capital of Culture. Retrieved February 1, 2014, from https://www.liverpool.ac.uk/impacts08/ publications/programme-overview-reports.

Isard, W. (1953). Regional Commodity Balances and Interregional Commodity Flows. The American Economic Review, 43(2), 167-180.

Jensen, R. C., Mandeville, T. D., \& Karunarante, N. D. (1979). Regional Economic Planning: Generation of Regional Input-Output Analysis. London: Croom Helm.

Ježek, J. (2010). Aplikace městského marketingu v praxi: vývoj, očekávání, realita (kritický pohled). E\&M Ekonomie a Management, 13(4), 123-134.

Kahn, R. F. (1931). The Relation of Home Investment to Unemployment. The Economic Journal, 41(162), 173-198.

Keynes, J. M. (1936). General Theory of Employment, Interest and Money. Palgrave Macmillan.

Kowalewski, J. (2012). Regionalization of national input-output tables: empirical evidence on the use of the FLQ formula (Hamburg Institute of International Economics Research Paper). Retrieved March 20, 2015, from http:// www.hwwi.org/uploads/tx_wilpubdb/HWWIResearch-Paper-126.pdf.

Liu, Y. (2014). Cultural Events and Cultural Tourism Development: Lessons from the European Capitals of Culture. European Planning Studies, 22(3), 498-514. doi:10.1080 /09654313.2012.75244. 
Leontief, W. (1936). Quantatative InputOutput relations in the economic system of the United States. Review of Economics and Statistics, 18(3), 105-125. doi:10.2307/1927837.

Leontief, W. (1986). Input output Economics. New York: Oxford University Press Inc.

Llop, M., \& Arauzo-Carod, J. M. (2011). Identifying the economic impact behind a cultural asset: an input-output subsystems analysis. The Annals of Regional Science, 49(3), 861-877. doi:10.1007/s00168-011-0464-2.

Macháček, J., Silovská, H., Říhová, G., \& Jílek, P. (2013). Regionální multiplikační efekt jako indikátor lokálního rozvoje. E\&M Ekonomie a Management, 16(3), 20-33.

Morrison, W. I., \& Smith, P. (1974). Nonsurvey Input-Output Techniques at the Small Area Level: An Evaluation. Journal of Regional Science, 14(1), 1-14. doi:10.1111/j.1467-9787.1974.tb00425.x.

Oxford Advanced Learner's Dictionary of Current English (6th ed.). (2000). Oxford: Oxford University Press.

Quesnay, F. (1758). Tableau economique. Paris: InstitutNationaled'EtudesDemographiques.

Raabová, T. (2010). Multiplikační efekty kulturních odvětví v České republice. Studie stavu, struktury, podmínek a financování umění $\checkmark C \check{R}$. Praha: Institut umění - Divadelní ústav.

Rojíček, M. (2007). Klíčová odvětví v české ekonomice $\mathrm{z}$ pohledu input-output analýzy. Statistika, 44(2), 133-145.
Round, J. I. (1978). An interregional inputoutput approach to the evaluation of nonsurvey methods. Journal of Regional Science, 18(2), 179-194.

Slach, O., Koutský, J., Novotný, J., \& Ženka, J. (2013). Creative Industries in the Czech Republic: A Spatial Perspective. E\&M Ekonomie a Management, 16(4), 14-29.

Slach, O., \& Ježek, J. (2015). Ondřej Slach, Jiř́ Ježek - Czechia. disP - The Planning Review, 51(1), 28-29. doi:10.1080/02513625.2 015.1038050 .

Šebová, M., Džupka, P., Hudec, O., \& Urbančíková, N. (2014). Promoting and financing cultural tourism in Europe through European capitals of culture: A case study of Košice, European capital of culture 2013. Amfiteatru Economic, 16(36), 655-670.

Tohmo, T. (2004). New developments in the use of location quotients to estimate regional input-output coefficients and multipliers. Regional Studies, 38(1), 43-54. doi:10.1080/0 0343400310001632262.

The Scottish Government. (2011). InputOutput Methodology Guide. Retrieved March 10, 2015, from http://www.scotland.gov.uk/ Topics/Statistics/Browse/Economy/InputOutput/MultiplierMethodology.

Ing. Marta Nosková University of West Bohemia Faculty of Economics Department of Geography mnosk@kpm.zcu.cz 


\section{Abstract}

\section{REGIONAL ECONOMIC EFFECTS OF THE EUROPEAN CAPITAL OF CULTURE PROJECT: THE USE OF INPUT-OUTPUT ANALYSIS}

\section{Marta Nosková}

The topic of economic effects of culture has become very popular recently. Particularly in connection with the European Capital of Culture, various studies examining economic impacts or methodologies for their monitoring are annually processed and the results are often part of evaluation reports related to the individual European Capital of Culture projects. Given the fact that in 2015 the European Capital of Culture is Plzen in the Czech Republic, it has been appropriate to determine what multiplier effects can be expected in connection with this event. Therefore, the focus was not only on the sector called "Arts, entertainment and recreation," but also on the other related industries that can be affected by the increase of tourists (i.e. "Wholesale and retail trade, repair of motor vehicles", "Transportation and storage" and "Accommodation and food service activities"). Therefore, the regional input-output model has been calculated and then multipliers of production, gross value added, income and employment have been derived for the sectors related to culture, wholesale and retail, transport, accommodation and food. The results have showed that these industries have the potential to affect the economy of the region and it can therefore be assumed that the aforementioned events, which take place within the Pilsen European Capital of Culture 2015, will bring considerable financial resources to the region, mainly through attracting foreign tourists and tourists from other regions of the country. The derived multipliers are computed from data for 2010 (more recent are not available) and, of course, they can also be used to determine economic effects of other events.

Key Words: Economic effects, culture, input-output, the Pilsen Region, ECoC.

JEL Classification: R15.

DOI: 10.15240/tul/001/2016-3-005 